\title{
48-60 Aylık Çocukların Dinleme Becerileri ile Sosyal Becerileri Arasındaki İlişkinin İncelenmesi
}

\author{
Özgül Polat, Demet Aydın
}

Temel Ĕ̌itim Bölümü, Atatürk Eğitim Fakültesi, Marmara Üniversitesi, İstanbul, Türkiye

Sorumlu Yazar: Özgül Polat, polatozgul@gmail.com

Makale Türü: Araştırma Makalesi

Kaynak Gösterimi: Polat, Ö., \& Aydın, D. (2021). 48-60 aylık çocukların dinleme becerileri ile sosyal becerileri arasındaki ilişkinin incelenmesi. Eğitimde Kuram ve Uygulama, 17(1), 39-53. doi: 10.17244/eku.909094

Etik Not: Araştırma ve yayın etiğine uyulmuştur. Bu çalışmada veriler 2020 yılı öncesi toplanmış olup, veri toplama sürecinde katılımcıların gönüllü katılımı gözetilmiştir.

\section{Investigation of the Relationship Between Listening Skills and Social Skills of 48-60 Month-Old Children}

$$
\text { Özgül Polat, Demet Aydın }
$$

Department of Basic Education, Atatürk Faculty of Education, Marmara University, Istanbul, Turkey

Corresponding Author: Özgül Polat, polatozgul@gmail.com

Article Type: Research Article

To Cite This Article: Polat, Ö., \& Aydın, D. (2021). 48-60 aylık çocukların dinleme becerileri ile sosyal becerileri arasındaki ilişkinin incelenmesi. Eğitimde Kuram ve Uygulama, 17(1), 39-53. doi: 10.17244/eku.909094

Ethical Note: Research and publication ethics were followed. In this study, the data were collected before 2020, and voluntary participation of study group was observed during the data collection period. 


\title{
48-60 Aylık Çocukların Dinleme Becerileri ile Sosyal Becerileri Arasındaki İliş̧kinin İncelenmesi
}

\author{
Özgül Polat ${ }^{1}$, Demet Aydın² \\ Temel Eğitim Bölümü, Atatürk Eğitim Fakültesi, Marmara Üniversitesi, İstanbul, Türkiye
}

ORCID: https://orcid.org/0000-0001-7426-5771

ORCID: https://orcid.org/0000-0002-5908-2886

Okul öncesi dönem birçok becerinin kazanımı için kritik bir dönemdir. Sosyal hayatta konuşma, okuma ve yazma ne kadar önemliyse dinleme de o kadar önemli ve gerekli bir beceridir. Ancak okul öncesi dönem üzerine yapılan çalışmalara bakıldığında dinleme ve sosyal beceriler üzerine çalışmaların yetersiz olduğu görülmektedir. Bu çalışmanın amacı; 48-60 aylık çocukların dinleme becerileri ile sosyal becerileri arasındaki ilişkinin incelemesidir. Nicel araştırma yöntemlerinden ilişkisel tarama modeli ile gerçekleştirilen araştırmanın verileri Okul Öncesi Dönem Çocuklarına Yönelik Dinleme Becerilerini Değerlendirme Ölçeği ve Okul Öncesi Sosyal Beceri Değerlendirme Ölçeği kullanılarak toplanmıştır. Araştırmanın katılımcı grubunu 48-60 ay grubundan 165 çocuk oluşturmaktadır. Katılımcıların seçiminde basit tesadüfî örnekleme yöntemi kullanılmıştır. Verilerin analizinde ilişki ve fark testlerinden yararlanılmıştır. Bu araştırma sonucunda 48-60 ay grubundan çocukların dinleme becerileri ve sosyal becerileri arasında pozitif yönde anlamlı bir ilişki olduğu sonucuna ulaşılmıştır. Çocukların cinsiyetlerinin ve annebaba öğrenim düzeyinin dinleme ve sosyal beceri düzeyleri üzerinde düzeyinde anlamlı fark yarattığı görülmektedir. Annelerin ve babaların öğrenim düzeyi arttıkça çocukların dinleme ve sosyal becerilerinin arttığı sonucuna ulaşılmıştır.
\end{abstract}

\section{Makale Bilgisi}

Anahtar kelimeler: Dinleme becerileri, Okul öncesi kurumları, Okul öncesi dönem çocukları, Sosyal beceriler

Makale Geçmişi:

Geliş: 03 Nisan 2021

Düzeltme: 13 Mayıs 2021

Kabul: 14 Mayıs 2021

Makale Türü: Araştırma Makalesi

\section{Investigation of the Relationship Between Listening Skills and Social Skills of 48-60 Month-Old}

\section{Children}

\begin{abstract}
The preschool period is a critical period for the acquisition of many skills. As speaking, reading, and writing are important in social life, listening is also an important and necessary skill. However, when looking at the studies on preschool period, it is seen that studies on listening and social skills are insufficient. The aim of this study is to investigate the relationship between listening skills and social skills of 48-60 month-old children. The data of the research, which was carried out with the relational scanning model, one of the quantitative research methods, was collected by using The Evaluation Scale of Preschool Period Children's Interception Skill and the teacher form of Preschool Social Skills Assessment Scale. The participant group of the study consists of 165 children from the 4860 months group. A simple random sampling method was used in the selection of the participants. Relationship and difference tests were used to analyze the data. As a result of this study, it was concluded that there is a positive significant relationship between the listening skills and social skills of 48-60 months-old children. It is seen that the gender of the children and the education level of parents make a significant difference in the level of listening and social skills. It was concluded that as the education level of mothers and fathers increased, the listening and social skills of children increased.
\end{abstract}

\section{Article Info}

Keywords: Listening skills, Preschool institutions, Preschool children, Social skills

Article History:

Received: 3 April 2021

Revised: 13 May 2021

Accepted: 14 May 2021

Article Type: Research Article

Etik Not: Araştırma ve yayın etiğine uyulmuştur. Bu çalışmada veriler 2020 yılı öncesi toplanmış olup, veri toplama sürecinde katılımcıların gönüllü katılımı gözetilmiştir. 


\section{Extended Summary}

\section{Introduction}

Social skills are the skills that positively influence the relationship of individual with his/her environment and are used by child to meet his/her social needs such as empathy, participating in group activities, helping each other and communicating with others (Lynch \& Simpson, 2010). Most of the researchers about social skills in early childhood and school success of children generally focus on school performance and emphasize the particular importance of social skills in the school performance (Aviles, Anderson \& Davila, 2006; Ergin \& Ermağan, 2011; Porath, 2003). The social skills which children begin to gain in preschool period may affect their social relationships in the coming years (Gülay \& Yenibayrak, 2010). Preschool period is the time frame preferred for making children gain the social skills such as collaboration, taking responsibility and controlling self-control (Kapıkıran, İvrendi \& Adak, 2006). These skills have a direct impact on social interactions in many aspects of life, including in family, workplace and school and on street (Türnüklü, 2004). It is more challenging for the children who have difficulty in gaining these skills, than for the children with social skills. For this reason, the children who have difficulty in social skills usually exhibit improper behavior patterns (Ekici, 2017; Gresham \& Elliott, 1990; Saitoğlu, 2020).

The more important speaking, reading and writing are in social life, the more important and necessary listening skill is. The best part of social relationships is based on telling and listening (Özbay, 2001). It is stated that listening skill is the basic communication element that enables the individual to maintain effective relationships with the environment, get information from the people around himself/herself, and recognize, understand and help people (Cihangir-Çankaya, 2015).

In Turkey, any study about the relationship between listening skills and social skills in preschool period could not be access in the literature. However, Abalı and Yazdic1 (2020) specified in their study that the 6th-grade students with high listening skills have high social-emotional learning skills. As a result of the research, it was seen that listening skills and social-emotional learning skills are not two skill groups that are independent of each other and that social-emotional skills develop as listening skills progress. Several international studies on receptive language and social skills were conducted (Benner et.al., 2007; Estrem, 2005) and it was suggested that the negative behaviors of preschoolers substantially result from weak receptive language skills. Based on the knowledge that the communication and discipline problems experienced at schools can be mitigated with an influential training about listening and social skills, it is believed that search of the relationship between both skills in preschool period will be of importance for future researchers.

Limited number of the studies regarding listening skills of preschoolers (Bay \& Seker, 2020; Florit et.al., 2009; Özer-Özkan, Çoşkun, 2015) and insufficiency of the researchers in literature that analyze the relationship between social skills and listening skills of children make us think that examination of these skills is significant. This study will contribute to literature by analyzing listening and social skills of the 48-to 60-month-old children. This study that aims to analyze the relationship between listening skills and social skills of the 48-60-month-old children sought the answer of the following question: Is there a correlation between the scores of Assessment Scale for Preschoolers' Listening Skills and the scores of Assessment Scale for Preschoolers' Social Skills?

\section{Methodology}

Correlational survey model was utilized as the quantitative research method in the research. Correlational survey model is a statistical model preferred to determine the presence of covariance orientation or pattern between two and more variables (Creswell, 2017). Purpose of this research is to reveal the relationships between listening skills and social skills of the 48-to 60-month-old children, so it was decided to use the correlational survey model. Research participants comprise 165 48-60-month-old children who go to preschools in Kars province. A simple random sampling method was applied to choose the participants. In this research, Assessment Scale for Preschoolers' Listening Skills (Özer Özkan \& Coşkun, 2015) and Assessment Scale for Preschoolers' Social Skills (Ömeroğlu et.al., 2014) were used as data collection tools. First, the necessary permissions for the research were obtained in data collection process. The preschool teachers who work in Kars province was secondly reached. They were informed about the research and requested to fill in the consent forms. Scales of each child were filled in on average within 10 minutes by his/her teacher. The data collection process was completed in two months.

The data attained in the research was turned into data set and analyzed in the SPSS package program by researchers. Descriptive analyses were first performed for the data obtained from the scales. Kolmogorov- Smirnov test was implemented to test normality of the distribution. Distribution was not normal; therefore, it was decided to use non-parametric tests in analysis of the research data. First, Mann-Whitney-U and Kruskal Wallis tests were 
applied to find out whether or not the data received from the Assessment Scale for Preschoolers' Listening Skills and the Assessment Scale for Preschoolers' Social Skills make up a significant difference according to gender and parents' educational level variables. Later, Spearman's correlation analysis was made with the aim of determining whether or not there is a significant relationship between the total scores obtained from the scales and the scores received from sub-dimensions.

\section{Conclusion}

It was concluded in this research that there is a positive significant relationship between listening skills and social skills of the 48-to 60-month-old children. It is seen that gender of children generate a significant difference at $\mathrm{p} \leq .05$ level in listening and social skills. Besides, it is observed that educational level of children's parents results in a significant difference at $\mathrm{p} \leq .05$ level in listening and social skills. In other words, listening and social skills of children increase as the educational level of their parents rise. In line with these results, it is suggested researchers and practitioners that the relationship between listening skills and social skills of children should be considered as the curricula for developing these skills are prepared. 


\section{Giriş}

Sosyal beceriler; bireyin çevresiyle ilişkisini olumlu yönde artıran empati, grup faaliyetlerine katılım, birbirlerine yardım etme, başkalarıyla iletişim kurma gibi çocuğun sosyal ihtiyaçları karşılayabilmek için kullandığı becerilerdir (Lynch ve Simpson, 2010). Çocukların erken dönem sosyal becerileri ve okul başarısı üzerine yapılan araştırmaların çoğu, genel olarak sosyal becerilere odaklanarak okul performansında sosyal becerilerin özellikle önemli olduğunu vurgulamaktadır (Aviles, Anderson \& Davila, 2006; Ergin \& Ermağan, 2011; Porath, 2003). Okul öncesi dönemde kazanılmaya başlanan sosyal beceriler çocuğun ileriki yaşantısındaki sosyal ilişkilerini etkileyebilmektedir (Gülay \& Yenibayrak, 2010). Okul öncesi dönemde kazandırılması hedeflenen sosyal beceriler; iş birliği yapma, sorumluluk alma, kendini kontrol etme gibi becerilerdir (Kapıkıran, İvrendi \& Adak, 2006). Bu beceriler ailede, iş yerinde, okulda, sokakta, yaşamın birçok alanında ortaya çıkan sosyal etkileşimleri doğrudan etkilemektedir (Türnüklü, 2004). Söz konusu becerileri ediniminde problem yaşayan çocuklar, karşılaştıkları sorunları çözmede sosyal becerilere sahip çocuklara göre daha fazla zorlanmaktadırlar. Bu sebeple sosyal becerilerde problem yaşayan çocuklarda çoğunlukla uygun olmayan davranış biçimleri görülür (Ekici, 2017; Gresham \& Elliott, 1990; Saitoğlu, 2020).

Sosyal becerilerle ilişkili yapılan çalışmalara bakıldığında bu becerilerin birçok değişkenle ilişkili olduğunu gösteren çalışmalar olduğu görülmektedir. Bu çalışmalardan birinde çocukların sosyal becerilerini bazı değişkenler açısından incelemiştir (Elibol, 2008). Ayrıca, sosyal beceri ile sosyal duygusal gelişimi inceleyen çalışmalar (Verduyn, Lord \& Forrest, 1990; Morgeson, Reider \& Campion, 2005; Kim vd., 2011) ve okul öncesi eğitiminin sosyal beceriler üzerindeki etkisini inceleyen (Çınar, 1990; Uğur, 1998; Özbek; 2003) çalışmalar bulunmaktadır. Bu çalışmalara ek olarak Dinçer ve arkadaşlarının (2019) yaptığı çalışmada, okul öncesi dönem çocukların sosyal beceri ve sosyal problem çözme becerileri arasında anlamlı bir ilişki olduğu, çocukların sosyal beceri düzeyleri düştükçe sosyal problem çözme becerilerinin de düştüğü ortaya çıkmıştır. Ayrıca, sosyal becerisi düşük olan çocukların akranlarıyla iletişimlerinde olumsuz yöntemler kullandıkları görüşmüştür. Benzer sonuçlar başka çalışmalarda da karşımıza çıkmaktadır (Bilici, 2019; Cillessen \& Bellmore, 2010; Arabacıoğlu \& Bağçeli, 2020).

Sosyal hayatta konuşma, okuma ve yazma ne kadar önemliyse dinleme de o kadar önemli ve gerekli bir beceridir. Toplumsal ilişkilerin büyük bir kısmı, anlatma ile dinlemeye dayanmaktadır (Özbay,2001). Dinleme; bilişsel, duyuşsal, devinişsel, fiziksel, fizyolojik, eğitsel, sosyal olmak üzere birçok boyutu olan ve bundan dolayı çok yönlü bir olgudur (Karadüz, 2010). Buradan yola çıarak; dinleme becerisinin, ailede, okulda, sosyal ortamlarda sıkça kullanıldığını söylemek mümkündür (Kemiksiz, 2017). Bireyin çevresiyle etkili ilişkiler sürdürmesinde, çevresindeki insanlardan bilgi almasında, insanları tanımasinda, anlamasında, yardım etmesinde dinleme becerisinin en temel iletişim öğesi olduğu ifade edilmektedir (Cihangir-Çankaya, 2015). Estrem (2005) yaptığı çalışmada olumsuz davranışlardan biri olan fiziksel şiddetin, daha az alıcı dil becerilerine sâhip olan erkek çocuklarda diğer erkek çocuklara oranla daha fazla olduğunu görmüş ve okul öncesi dönem çocuklarında görülen olumsuz davranışların, büyük ölçüde zayıf alıcı dil becerileri nedeniyle meydana geldiğini belirtmiştir.

Alan yazın incelendiğinde okul öncesi dönemde dinleme becerileri ile sosyal beceriler arasındaki ilişkiyi inceleyen yurt içinde yapılan bir çalışmaya rastlanmamıştır. Ancak, Abalı \& Yazıcı (2020) tarafından gerçekleştirilen bir çalışmada, dinleme becerileri yüksek olan altıncı sınıf öğrencilerinin sosyal duygusal öğrenme becerilerinin de yüksek olduğu belirtilmiştir. Araştırmanın sonucunda dinleme becerisi ile sosyal ve duygusal öğrenme becerileri birbirinden bağımsız iki beceri olmadığı dinleme becerileri geliştikçe sosyal ve duygusal becerilerin de geliştiği görülmüştür. Yurt dışında yapılan çalışmalarda alıcı dil ve sosyal beceriler üzerine çalışmalara rastlanmış (Benner vd., 2007; Estrem, 2005) okul öncesi dönem çocuklarında görülen olumsuz davranışların, büyük ölçüde zayıf alıcı dil becerileri nedeniyle meydana geldiğini belirtilmiştir. Okullarda yaşanan iletişim ve disiplin sorunlarının etkili bir dinleme ve sosyal beceri eğitimiyle azaltılabileceği bilgisinden yola çıkılarak okul öncesi dönemde bu iki beceri arasındaki ilişkinin araştırılmasının ileriki araştırmalar için önem oluşturacağına inanılmaktadır.

Kemiksiz (2017), dinleme becerisi üzerine yapılan çalışmalara bakıldığında, katılımcıların genelde ortaokul ve lisans seviyesindeki öğrencilerden tercih edildiğini belirtmiştir. Okul öncesi dönemde çocukların dinleme becerilerini inceleyen çalışmaların (Bay \& Seker, 2020; Florit vd., 2009; Özer-Özkan \& Çoşkun, 2015) sınırlı olması ve alan yazında çocukların sosyal becerileri ile dinleme becerileri arasındaki ilişkiyi inceleyen çalışmaların yetersiz olması nedeniyle bu becerilerin incelenmesinin önemli olduğu düşünülmektedir. Bu çalışma 48-60 aylık çocukların dinleme becerileri ile sosyal becerileri arasındaki ilişki incelenerek alan yazına katkı sağlayacaktır.

48-60 aylık çocukların dinleme becerileri ile sosyal becerileri arasındaki ilişkinin incelemesini amaçlayan bu çalışmada "Okul Öncesi Dönem Çocuklarına Yönelik Dinleme Becerilerini Değerlendirme Ölçeği puanları ile Okul Öncesi Sosyal Beceri Değerlendirme Ölçeğinin puanları arasında ilişki var mıdır?" sorusuna cevap aranmıştır.

Bu problemden yola çıkılarak aşağıdaki alt problemler belirlenmiştir:

- Okul Öncesi Dönem Çocuklarına Yönelik Dinleme Becerilerini Değerlendirme Ölçeğinin tamamından ve alt boyutlarından elde edilen puanlar cinsiyete göre farklılaşmakta mıdır?

- Okul Öncesi Sosyal Beceri Değerlendirme Ölçeğinin tamamından ve alt boyutlarından elde edilen puanlar cinsiyete göre farklılaşmakta mıdır? 
- Okul Öncesi Dönem Çocuklarına Yönelik Dinleme Becerilerini Değerlendirme Ölçeğinin tamamından ve alt boyutlarından elde edilen puanlar anne ve baba öğrenim düzeyine göre farklılaşmakta mıdır?

Okul Öncesi Sosyal Beceri Değerlendirme Ölçeğinin tamamından ve alt boyutlarından elde edilen puanlar anne ve baba öğrenim düzeyine göre farklılaşmakta mıdır?

- Okul Öncesi Dönem Çocuklarına Yönelik Dinleme Becerilerini Değerlendirme Ölçeğinin tamamından ve alt boyutlarından elde edilen puanlar ile Okul Öncesi Sosyal Beceri Değerlendirme Ölçeğinin tamamından ve alt boyutlarından elde edilen puanlar arasında ilişki var mıdır?

\section{Yöntem}

Araştırma nicel araştırma yöntemlerinden ilişkisel tarama modelinde gerçekleştirilmiştir. İlişkisel tarama modeli; iki ve daha çok sayıdaki değişken arasında birlikte değişime yönelim veya örüntüsünü belirlemek amacıyla tercih edilen bir istatistiksel modeldir (Creswell, 2017). Bu araştırmada, 48-60 ay grubu çocukların dinleme becerileri ve sosyal becerileri arasında var olan ilişkilerin açığa çıkarılabilmesi amaçlandığı için ilişkisel tarama modelinden yararlanılmasına karar verilmiştir.

\section{Katılımcilar}

Araştırmanın katılımcılarını Kars ilindeki okul öncesi eğitim kurumlarına devam etmekte olan 48-60 ay grubundan 165 çocuk oluşturmaktadır. Katılımcıların seçilmesinde basit tesadüfî örnekleme yöntemi kullanılmıştır. Katılımcıları oluşturan okul öncesi dönem çocukları ve ebeveynlerine ait demografik özelliklerin yüzde ve frekans dağılımları verilmiştir. Bulgular Tablo 1'de sunulmaktadır:

Tablo 1. Katılımcılara ilişkin demografik bilgilerin frekans ve yüzdelik dağılımı

\begin{tabular}{lccc}
\hline \multicolumn{2}{c}{ Demografik bilgiler } & f & $\%$ \\
\hline Cinsiyet & Kız & 94 & 57,0 \\
& Erkek & 71 & 43,0 \\
Annenin Öğrenim Düzeyi & Ortaokul- Lise & 66 & 38,0 \\
& Ön Lisans-Lisans & 64,8 & 21,2 \\
Babanın Öğrenim Düzeyi & Okuma Bilmeyen-İlkokul & 35 & 28,5 \\
& Ortaokul- Lise & 47 & 43,0 \\
& Ön Lisans-Lisans & 71 & 28,5 \\
\hline
\end{tabular}

Katılımcıları oluşturan 165 okul öncesi dönem çocuğunun cinsiyetine ilişkin bulgulara bakıldığında çocukların 94’ü $(\% 57,0)$ kız, 71’i $(\% 43,0)$ erkektir. Bu çocukların ebeveynlerinin öğrenim düzeylerine bakıldığında annelerin öğrenim düzeyinde okuma yazma bilmeyen ve ilkokul mezunu annelerin sayısı $66(40,0)$, ortaokul ve lise mezunu annelerin sayıs1 $64(\% 38,8)$, ön lisans ve lisan mezunu annelerin sayısı $35(\% 21,2)$ olduğu görülmektedir. Babaların öğrenim düzeyinde okuma yazma bilmeyen ve ilkokul mezunu babaların sayısı $47(28,5)$, ortaokul ve lise mezunu babaların sayısı 71 (\%43,0), ön lisans ve lisan mezunu annelerin sayısı 47’dir $(\% 28,5)$.

\section{Veri Toplama Araçları}

Bu araştırmada Okul Öncesi Dönem Çocuklarına Yönelik Dinleme Becerilerini Değerlendirme Ölçeği (Özer Özkan ve Coşkun, 2015) ve Okul Öncesi Sosyal Beceri Değerlendirme Ölçeği (Ömeroğlu vd., 2014) veri toplama araçları kullanılmıştır.

Okul Öncesi Dönem Çocuklarına Yönelik Dinleme Becerilerini Değerlendirme Ölçeği (DBÖ): Ölçek Özer Özkan ve Coşkun tarafından (2015) geliştirilmiştir. Ölçeğin yapı geçerliği için Açımlayıcı Faktör Analizi (AFA) ve 
Doğrulayıcı Faktör Analizi (DFA) yapılmıştır. Yapılan AFA sonucunda, toplam varyansın \%70.07'sini açılayan, bilişsel ve sosyal olmak üzere, iki faktörden oluşan bir yapı elde edilmiştir. AFA ile önerilen faktör modeli, DFA ile test edilmiştir. DFA sonucu elde edilen uyum indekslerinden RMSEA değeri 0.09 ve CFI değeri ise 0.98 olarak hesaplanmıştır. DFA sonuçları, iki faktörlü yapının yeterli uyuma sahip olduğunu göstermiştir. Geliştirilen ölçeğin iç tutarlılık güvenirliğine ilişkin hesaplanan Cronbach Alfa katsayısı 0.94 olarak elde edilmiştir Okul Öncesi Dönem Çocuklarının Dinleme Becerilerini Değerlendirme Ölçeğinin geçerli ve güvenilir olduğu kabul edilmiştir. Ölçek (1) Hiçbir zaman, (2) Ara sıra, (3) Çoğunlukla, (4) Her zaman şeklinde 4'lü likert tipinde yapılandırılmıştır ve öğretmenler tarafından doldurulmaktadır. Ölçek iki alt boyuttan oluşmaktadır. Bu boyutlar: Sosyal Davranışlar ve Bilişsel Davranışlar alt boyutlarıdır. Bu boyutlardan; sosyal boyut 9, bilişsel boyut ise 21 olmak üzere toplam 30 maddeden oluşmaktadır.

Okul Öncesi Sosyal Beceri Değerlendirme Ölçeği (OSBED) Öğretmen Formu: Ölçek Ömeroğlu vd. (2014) tarafından öğretmen formu olarak geliştirilmiş̧tir. Ölçeğin faktör yapısının incelenmesine ve güvenirlik değerlerinin hesaplanmasına ilişkin analizler sonucu OSBED öğretmen formu 4 faktör ve 49 madde ile tanımlanmıştır. Ölçeğe uygulanan doğrulayıcı faktör analizi sonucunda, RMSEA değeri 0.09, RMR değeri .06, CFI değeri 0.96, NFI .95 ve GFI .66 olarak hesaplanmıştır. OSBED öğretmen formu puanlarının güvenirliği için Cronbach Alpha katsayısı hesaplanmıştır. Alfa değeri başlangıç becerileri için .89, akademik beceriler için .88, arkadaşlık becerileri için .92, duygularını yönetme becerileri için .92 'dir. Bulgular ölçeğin okul öncesi çocuklarının sosyal becerilerini ölçmek için geliştirilmiş geçerli ve güvenilir bir ölçme aracı olduğunu desteklemektedir. Ölçek 4 alt boyuttan oluşmaktadır. Bu boyutlar: Başlangıç Becerileri, Akademik Destek Becerileri, Arkadaşlık Becerileri, Duygularını Yönetme Becerileri alt boyutlarıdır.

\section{Veri Toplama Süreci}

Veri toplama sürecinde ilk olarak araştırma için gerekli izinler ilgili Milli Eğitim Müdürlüğünden alınmıştır. Ardından, Kars ilinde görev yapan okul öncesi öğretmenlerine ulaşılmıştır. Okul öncesi öğretmenlerine araştırma hakkında bilgi verilmiş ve onam formunu doldurmaları istenmiştir. Ölçekler her bir çocuk için kendi öğretmeni tarafından ortalama 10 dakikada doldurulmuştur. Veri toplama süreci iki ayda tamamlanmıştır.

\section{Verileri Analizi}

Araştırmada elde edilen veriler araştırmacılar tarafından veri seti haline dönüştürülerek, SPSS paket programında analiz edilmiştir. İlk olarak, ölçeklerden elde edilen verilere ait betimsel analizler gerçekleştirilmiş ve dağ 1 lımın normalliğini test etmek amacıyla Kolmogorov - Smirnov testi uygulanmıştır. Dağılımın normal olmaması nedeniyle araştırma verilerinin analizinde parametrik olmayan testlerden yararlanılmasına karar verilmiştir. Ardından, Okul Öncesi Dönem Çocuklarına Yönelik Dinleme Becerilerini Değerlendirme ve Okul Öncesi Sosyal Beceri Değerlendirme ölçeklerinden elde edilen verilerin cinsiyet ve anne-baba öğrenim düzeyi değişkenlerine göre anlamlı bir farklılık oluşturup oluşturmadığını belirlemek amacıyla Mann Whitney-U ve Kruskal Wallis testleri gerçekleştirilmiştir. Ardından, ölçeklerden elde edilen toplam puanlar ve alt boyutlardan elde edilen puanlar arasında anlamlı bir ilişki olup olmadığını belirlemek amacıyla Spearman's kolerasyon analizi yapılmıştır.

\section{Bulgular}

Araştırma sürecinde elde edilen verilere ilişkin bulgular aşağıda tablolar halinde sunulmuş ve yorumlanmıştır. DBÖ ve OSBED Öğretmen Formuna ilişkin betimsel istatistikler Tablo 2'de sunulmaktadır:

Tablo 2. DBÖ ve OSBED Öğretmen Formuna ilişkin betimsel istatistikler

\begin{tabular}{|c|c|c|c|c|c|c|c|c|c|}
\hline & Değişkenler & $\mathbf{n}$ & Min & $\operatorname{Max}$ & $\bar{x}$ & sd & $s h_{\bar{x}}$ & $y_{1}$ & $\boldsymbol{\beta}_{2}$ \\
\hline \multirow[t]{3}{*}{ DBÖ } & Sosyal Davranışlar Alt Boyutu & 165 & 1,78 & 4 & 3,281 &, 581 & 045 &,- 647 &,- 347 \\
\hline & Bilişsel Davranışlar Alt Boyutu & 165 & 1,14 & 4 & 3,122 & 655 & 050 &,- 942 & 687 \\
\hline & $\begin{array}{c}\text { Dinleme Becerileri } \\
\text { Değerlendirme Ölçeği Toplam } \\
\text { Puanı }\end{array}$ & 165 & 1,37 & 4 & 3,170 &, 591 & ,046 &,- 750 & ,108 \\
\hline OSBED Öğretmen & Başlangıç Becerileri Alt Boyutu & 165 & 1,42 & 5 & 4,018 & ,784 &, 061 &,- 912 & ,049 \\
\hline
\end{tabular}




\begin{tabular}{|c|c|c|c|c|c|c|c|c|c|}
\hline \multirow[t]{4}{*}{ Formu } & $\begin{array}{c}\text { Akademik Destek Becerileri Alt } \\
\text { Boyutu }\end{array}$ & 165 & 1,92 & 5 & 3,941 & ,760 & ,059 &,- 660 &,- 447 \\
\hline & $\begin{array}{c}\text { Arkadaşlık Becerileri Alt } \\
\text { Boyutu }\end{array}$ & 165 & 1,77 & 5 & 3,941 & ,766 & ,059 &,- 905 &, 552 \\
\hline & $\begin{array}{l}\text { Duygularını Yönetme Becerileri } \\
\text { Alt Boyutu }\end{array}$ & 165 & 1,58 & 5 & 3,721 & 863 & ,067 &,- 582 &,- 336 \\
\hline & $\begin{array}{l}\text { Sosyal Beceri Değerlendirme } \\
\text { Ölçeği Toplam Puanı }\end{array}$ & 165 & 2,06 & 5 & 3,906 & ,732 & 057 &,- 782 &,- 128 \\
\hline
\end{tabular}

Tablo 2'de yer alan analiz sonuçlarına göre; DBÖ toplam ve alt boyutlarının puanlarına ait çarpıklık basıklık değerlerinin Sosyal Davranışlar alt boyutu $(\mathrm{y} l=-64, \beta 2=-.34$, Bilişsel Davranışlar alt boyutu $(\mathrm{y} 1=-, 75, \beta 2=-, 68)$, toplam puanı $(\mathrm{y} 1=-, 75 \beta 2=-, 10) \pm 1.00$ aralığında olduğu görülmektedir.

OSBEP öğretmen formunun toplam ve alt boyutlarının puanlarına ait çarpıklık basıklık değerlerinin Başlangıç Becerileri alt boyutu $(\mathrm{y} 1=-, 91, \beta 2=, 04)$, Akademik Destek Becerileri alt boyutu $(\mathrm{y} 1=-, 66, \beta 2=-, 44)$, Arkadaşlık Becerileri alt boyutu $(\mathrm{y} 1=-, 90, \beta 2=-, 55)$, Duygularını Yönetme Becerileri alt boyutu $(\mathrm{y} 1=-, 58, \beta 2=-, 33)$, toplam puanı $(\mathrm{y} 1=-, 78 \beta 2=-, 12) \pm 1.00$ aralığında olduğu görülmektedir. Bu referanslarla birlikte, verilerin dağılımının normalliğini test etmek amacıyla Kolmogrov Smirnov testinden yararlanılmıştır. Normallik testi sonuçlarına ilişkin bulgular Tablo 3'te sunulmaktadır:

Tablo 3. Ölçeklerin toplam puanı ve alt ölçeklere ilişkin Kolmogorov- Smirnov testi sonuçları

\begin{tabular}{|c|c|c|c|c|}
\hline \multicolumn{2}{|c|}{ Kolmogorov-Smirnov } & \multirow{2}{*}{$\begin{array}{c}\mathbf{S} \\
, 113\end{array}$} & \multirow{2}{*}{$\begin{array}{c}\mathbf{F} \\
165\end{array}$} & \multirow{2}{*}{$\begin{array}{c}\mathbf{p} \\
, 000\end{array}$} \\
\hline DBÖ & Sosyal Davranışlar Alt Boyutu & & & \\
\hline & Bilişsel Davranışlar Alt Boyutu &, 111 & 165 &, 000 \\
\hline & $\begin{array}{l}\text { Dinleme Becerileri } \\
\text { Değerlendirme Ölçeği Toplam Puanı }\end{array}$ &, 105 & 165 &, 000 \\
\hline \multirow[t]{5}{*}{ OSBED Öğretmen Formu } & Başlangıç Becerileri Alt Boyutu &, 147 & 165 &, 000 \\
\hline & Akademik Destek Becerileri Alt Boyutu &, 143 & 165 &, 000 \\
\hline & Arkadaşlık Becerileri Alt Boyutu &, 112 & 165 &, 000 \\
\hline & Duygularını Yönetme Becerileri Alt Boyutu &, 111 & 165 &, 000 \\
\hline & $\begin{array}{c}\text { Sosyal Beceri Değerlendirme Ölçeği Toplam } \\
\text { Puanı }\end{array}$ &, 118 & 165 &, 000 \\
\hline
\end{tabular}

Tablo 3'te yer alan analiz sonuçlarına göre; normallik testi sonuçlarına bakıldığında hem DBÖ’nün hem de OSBED Öğretmen Formunun puanlarının manidarlık düzeylerinin 0,05 'ten küçük olduğu görülmüştür $(\mathrm{P}<, 05)$. Her bir ölçekten alınan puanların alfa değerleri 0,05 'ten küçük olduğu için verilerin normal dağılmadığı belirlenmiştir.

Katılımcıları oluşturan okul öncesi dönem çocuklarının cinsiyet değişkenine göre DBÖ’nün toplam puanı ve ölçeğin alt boyutlarına ilişkin puanlar Mann Whitney-U testi ile analiz edilmiştir. Bulgular Tablo 4 'te sunulmaktadır: 
Tablo 4. Okul öncesi dönem çocuklarının cinsiyet değişkenine göre DBÖ’nün Toplam Puanı ve Ölçeğin Alt Boyutları için Mann Whitney-U testi sonuçları

\begin{tabular}{|c|c|c|c|c|c|c|}
\hline & Cinsiyet & $\mathbf{n}$ & Sira Ortalaması & $\begin{array}{l}\text { Toplam } \\
\text { Ortalama }\end{array}$ & $\mathbf{U}$ & $\mathbf{p}$ \\
\hline \multirow{3}{*}{ Sosyal Davranışlar Alt Boyutu } & $\mathrm{K} 1 \mathrm{z}$ & 94 & 93,77 & 8814,50 & \multirow{3}{*}{2324,500} & \multirow{3}{*}{,001 } \\
\hline & & & & & & \\
\hline & Erkek & 71 & 68,74 & 4880,50 & & \\
\hline \multirow{2}{*}{$\begin{array}{l}\text { Bilişsel Davranışlar } \\
\text { Alt Boyutu }\end{array}$} & $\mathrm{K} 1 \mathrm{z}$ & 94 & 94,19 & 8853,50 & \multirow{2}{*}{2285,500} & \multirow{2}{*}{, 001} \\
\hline & Erkek & 71 & 68,19 & 4841,50 & & \\
\hline \multirow{2}{*}{$\begin{array}{c}\text { DBÖ } \\
\text { Toplam Puanı }\end{array}$} & $\mathrm{K} 1 \mathrm{z}$ & 94 & 94,86 & 8916,50 & \multirow{2}{*}{2222,500} & \multirow{2}{*}{, 000} \\
\hline & Erkek & 71 & 67,30 & 4778,50 & & \\
\hline
\end{tabular}

Tablo 4'te yer alan analiz sonuçlarına göre; DBÖ'nün toplam puanı (U=2222,500 p<,05), Sosyal Davranışlar alt boyutundan $(U=2324,500 p<, 05)$ ve Bilişsel Davranışlar alt boyutundan $(U=2285,500 p<, 05)$ elde edilen bulgularda cinsiyet değişkeni arasındaki fark Mann Whitney U testine göre anlamlı bulunmuştur.

Katılımcıları oluşturan okul öncesi dönem çocuklarının cinsiyet değişkenine göre OSBED Öğretmen Formunun toplam puanı ve ölçeğin alt boyutlarına ilişkin puanlar Mann Whitney $\mathrm{U}$ testi ile analiz edilmiştir. Bulgular Tablo 5'te sunulmaktadır:

Tablo 5. Okul öncesi dönem çocuklarının cinsiyet değişkenine göre DBÖ’nün Toplam Puanı ve Ölçeğin Alt Boyutları için Mann Whitney-U testi sonuçları

\begin{tabular}{|c|c|c|c|c|c|c|}
\hline & Cinsiyet & $\mathbf{n}$ & Sira Ortalaması & $\begin{array}{l}\text { Toplam } \\
\text { Ortalama }\end{array}$ & $\mathbf{U}$ & $\mathbf{p}$ \\
\hline \multirow{3}{*}{ Başlangıç Becerileri Alt Boyutu } & Kız & 94 & 94,31 & 8865,50 & \multirow{3}{*}{2273,500} & \multirow{3}{*}{, 000} \\
\hline & & & & & & \\
\hline & Erkek & 71 & 68,02 & 4829,50 & & \\
\hline \multirow{3}{*}{ Akademik Destek Becerileri Alt Boyutu } & $\mathrm{K} 1 \mathrm{z}$ & 94 & 96,75 & 9094,50 & \multirow{3}{*}{2044,500} & \multirow{3}{*}{, 000} \\
\hline & & & & & & \\
\hline & Erkek & 71 & 64,80 & 4600,50 & & \\
\hline \multirow{3}{*}{ Arkadaşlık Becerileri Alt Boyutu } & $\mathrm{K} 1 \mathrm{z}$ & 94 & 95,10 & 8939,50 & \multirow{3}{*}{2199,500} & \multirow{3}{*}{, 000} \\
\hline & & & & & & \\
\hline & Erkek & 71 & 66,98 & 4755,50 & & \\
\hline \multirow{2}{*}{$\begin{array}{c}\text { Duygularını Yönetme Becerileri Alt } \\
\text { Boyutu }\end{array}$} & $\mathrm{K} 1 \mathrm{z}$ & 94 & 93,83 & 8820,00 & \multirow{2}{*}{2319,000} & \multirow{2}{*}{, 001} \\
\hline & Erkek & 71 & 68,66 & 4875,00 & & \\
\hline \multirow{3}{*}{ OSBED Öğretmen Formu Toplam Puanı } & $\mathrm{K} 1 \mathrm{z}$ & 94 & 96,15 & 9038,50 & \multirow{3}{*}{2100,500} & \multirow{3}{*}{, 000} \\
\hline & & & & & & \\
\hline & Erkek & 71 & 65,58 & 4656,50 & & \\
\hline
\end{tabular}

Tablo 5'te yer alan analiz sonuçlarına göre; OSBED Öğretmen Formunun toplam puanı $(U=2100,500 p<, 05)$, Başlangıç Becerileri alt boyutundan ( $U=2273,500$ p $<, 05)$, Akademik Destek Becerileri alt boyutundan ( $U=2044,500$ 
$\mathrm{p}<, 05)$, Arkadaşlık Becerileri alt boyutundan $(\mathrm{U}=2199,500 \mathrm{p}<, 05)$ ve Duygularını Yönetme Becerileri alt boyutundan $(\mathrm{U}=2319,000 \mathrm{p}<, 05)$ elde edilen bulgularda cinsiyet değişkeni arasındaki fark anlamlı bulunmuştur.

Katılımcıları oluşturan okul öncesi dönem çocuklarının annelerinin öğrenim düzeyi değişkenine göre DBÖ’nün toplam puanından ve ölçeğin alt boyutlarından elde ettikleri puanların farklılaşıp farklılaşmadığını belirlemek üzere yapılan Kruskal Wallis-H testi ile analiz edilmiştir. Bulgular Tablo 6'da sunulmaktadır:

Tablo 6. Anne öğrenim düzeyi değişkenine göre DBÖ’nün Toplam Puanı ve Ölçeğin Alt Boyutları için Kruskal Wallis-H testi sonuçları

\begin{tabular}{|c|c|c|c|c|c|c|}
\hline & $\begin{array}{c}\text { Anne Öğrenim } \\
\text { Düzeyi }\end{array}$ & n & Sira Ort. & sd & $\mathrm{x}^{2}$ & $\mathbf{p}$ \\
\hline \multirow[t]{3}{*}{$\begin{array}{l}\text { Sosyal Davranışlar } \\
\text { Alt Boyutu }\end{array}$} & $\begin{array}{c}\text { Okuma Bilmeyen- } \\
\text { İlkokul }\end{array}$ & 66 & 68,27 & 2 & 15,46 &, 000 \\
\hline & Ortaokul- Lise & 64 & 84,96 & & & \\
\hline & $\begin{array}{l}\text { Ön Lisans- } \\
\text { Lisans }\end{array}$ & 35 & 107,19 & & & \\
\hline \multirow[t]{3}{*}{$\begin{array}{l}\text { Bilişsel Davranışlar } \\
\text { Alt Boyutu }\end{array}$} & $\begin{array}{l}\text { Okuma Bilmeyen- } \\
\text { İlkokul }\end{array}$ & 66 & 64,92 & 2 & 18,25 &, 000 \\
\hline & Ortaokul- Lise & 64 & 89,45 & & & \\
\hline & $\begin{array}{l}\text { Ön Lisans- } \\
\text { Lisans }\end{array}$ & 35 & 105,29 & & & \\
\hline \multirow[t]{3}{*}{ DBÖ Toplam Puanı } & $\begin{array}{l}\text { Okuma Bilmeyen- } \\
\text { İlkokul }\end{array}$ & 66 & 64,78 & 2 & 19,59 &, 000 \\
\hline & Ortaokul- Lise & 64 & 88,43 & & & \\
\hline & $\begin{array}{l}\text { Ön Lisans- } \\
\text { Lisans }\end{array}$ & 35 & 107,43 & & & \\
\hline
\end{tabular}

Tablo 6'da yer alan analiz sonuçlarına göre; annelerin öğrenim düzeyinin, DBÖ’nün toplam puanlarında ve alt boyutlarında anlamlı bir şekilde farklılaştığı görülmektedir. Analiz sonucunda, grupların sıra ortalamaları arasındaki fark istatistiksel olarak anlamlı bulunmuştur. Bu bulgular annelerin öğrenim düzeyleri arttıkça DBÖ’nün toplam puanlarının arttığı görülmektedir $(\mathrm{x} 2=19,26 ; \mathrm{p}<, 05)$. Ayrıca Sosyal Davranışlar $(\mathrm{x} 2=15,46 ; \mathrm{p}<, 05)$ ve Bilişsel Davranışlar alt boyutlarında $(x 2=18,25 ; \mathrm{p}<, 05)$ anlamlı bir farklılaşma olduğu görülmektedir.

Katılımcıları oluşturan okul öncesi dönem çocuklarının annelerinin öğrenim düzeyi değişkenine göre OSBED Öğretmen Formunun toplam puanından ve ölçeğin alt boyutlarından elde ettikleri puanların farklılaşıp farklılaşmadığını belirlemek üzere yapılan Kruskal Wallis-H testi ile analiz edilmiştir. Bulgular Tablo 7'de sunulmaktadır:

Tablo 7. Anne öğrenim düzeyi değişkenine göre OSBED Öğretmen Formuna Toplam Puanı ve Ölçeğin Alt Boyutları için Kruskal Wallis-H testi sonuçları

\begin{tabular}{|c|c|c|c|c|c|c|}
\hline & $\begin{array}{c}\text { Anne Ö̆ğrenim } \\
\text { Düzeyi }\end{array}$ & $\bar{n}$ & Sira Ort. & sd & $\overline{x^{2}}$ & $\bar{p}$ \\
\hline \multirow[t]{3}{*}{$\begin{array}{c}\text { Başlangıç Becerileri } \\
\text { Alt Boyutu }\end{array}$} & $\begin{array}{l}\text { Okuma Bilmeyen- } \\
\text { İlkokul }\end{array}$ & 66 & 62,59 & 2 & 26,63 & 000 \\
\hline & $\begin{array}{l}\text { Ortaokul- } \\
\text { Lise }\end{array}$ & 64 & 87,56 & & & \\
\hline & $\begin{array}{l}\text { Ön Lisans- } \\
\text { Lisans }\end{array}$ & 35 & 113,14 & & & \\
\hline $\begin{array}{c}\text { Akademik Destek Becerileri } \\
\text { Alt Boyutu }\end{array}$ & $\begin{array}{l}\text { Okuma Bilmeyen- } \\
\text { İlkokul }\end{array}$ & 66 & 64,14 & 2 & 20,90 &, 000 \\
\hline
\end{tabular}




\begin{tabular}{|c|c|c|c|c|c|c|}
\hline & $\begin{array}{l}\text { Ortaokul- } \\
\text { Lise }\end{array}$ & 64 & 88,72 & & & \\
\hline & $\begin{array}{l}\text { Ön Lisans- } \\
\text { Lisans }\end{array}$ & 35 & 108,10 & & & \\
\hline \multirow{3}{*}{$\begin{array}{l}\text { Arkadaşlik } \\
\text { Becerileri Alt } \\
\text { Boyutu }\end{array}$} & $\begin{array}{l}\text { Okuma Bilmeyen- } \\
\text { İlkokul }\end{array}$ & 66 & 62,95 & 2 & 22,58 &, 000 \\
\hline & $\begin{array}{l}\text { Ortaokul- } \\
\text { Lise }\end{array}$ & 64 & 90,04 & & & \\
\hline & $\begin{array}{l}\text { Ön Lisans- } \\
\text { Lisans }\end{array}$ & 35 & 107,93 & & & \\
\hline \multirow{3}{*}{$\begin{array}{l}\text { Duygularını } \\
\text { Yönetme Becerileri } \\
\text { Alt Boyutu }\end{array}$} & $\begin{array}{l}\text { Okuma Bilmeyen- } \\
\text { İlkokul }\end{array}$ & 66 & 70,14 & 2 & 9,23 &, 010 \\
\hline & $\begin{array}{l}\text { Ortaokul- } \\
\text { Lise }\end{array}$ & 64 & 87,60 & & & \\
\hline & $\begin{array}{l}\text { Ön Lisans- } \\
\text { Lisans }\end{array}$ & 35 & 98,83 & & & \\
\hline \multirow{3}{*}{$\begin{array}{l}\text { OSBED Ögrretmen Formu } \\
\text { Toplam } \\
\text { Puanı }\end{array}$} & $\begin{array}{c}\text { Okuma Bilmeyen- } \\
\text { İlkokul }\end{array}$ & 66 & 63,27 & 2 & 22,82 & ,000 \\
\hline & Ortaokul- Lise & 64 & 89,01 & & & \\
\hline & $\begin{array}{l}\text { Ön Lisans- } \\
\text { Lisans }\end{array}$ & 35 & 109,23 & & & \\
\hline
\end{tabular}

Tablo 7'de yer alan analiz sonuçlarına göre; annelerin öğrenim düzeyinin, OSBED Öğretmen Formunun toplam puanlarında ve alt boyutlarında anlamlı bir şekilde farklılaştığı görülmektedir. Bu bulgular annelerin öğrenim düzeyleri arttıkça çocukların OSBED Öğretmen Formunun toplam puanlarının arttı̆ğ görülmektedir (x2=22,82; $\mathrm{p}<, 05)$. Ayrıca Başlangıç Becerileri $(\mathrm{x} 2=26,63 ; \mathrm{p}<, 05)$, Akademik Destek Becerileri $(\mathrm{x} 2=29,90 ; \mathrm{p}<, 05)$, Arkadaşlık Becerileri $(\mathrm{x} 2=22,58 ; \mathrm{p}<, 05)$ ve Duygularını Yönetme Becerileri alt boyutlarında $(\mathrm{x} 2=9,23 ; \mathrm{p}<, 05)$ anlamlı bir farklılaşma olduğu görülmektedir.

Katılımcıları oluşturan okul öncesi dönem çocuklarının babalarının öğrenim düzeyi değişkenine göre DBÖ'nün toplam puanından ve ölçeğin alt boyutlarından elde ettikleri puanların farklılaşıp farklılaşmadığını belirlemek üzere yapılan Kruskal Wallis-H testi ile analiz edilmiştir. Bulgular Tablo 8'de sunulmaktadır:

Tablo 8. Baba öğrenim düzeyi değişkenine göre DBÖ'nün Toplam Puanı ve Ölçeğin Alt Boyutları için Kruskal Wallis-H testi sonuçları

\begin{tabular}{|c|c|c|c|c|c|c|}
\hline & $\begin{array}{c}\text { Baba Öğrenim } \\
\text { Düzeyi }\end{array}$ & n & Sira Ort. & sd & $\overline{x^{2}}$ & $\mathbf{p}$ \\
\hline \multirow[t]{3}{*}{$\begin{array}{l}\text { Sosyal Davranışlar } \\
\text { Alt Boyutu }\end{array}$} & $\begin{array}{c}\text { Okuma Bilmeyen- } \\
\text { İlkokul }\end{array}$ & 47 & 68,93 & 2 & 19,68 & ,000 \\
\hline & $\begin{array}{l}\text { Ortaokul- } \\
\text { Lise }\end{array}$ & 71 & 75,30 & & & \\
\hline & $\begin{array}{l}\text { Ön Lisans- } \\
\text { Lisans }\end{array}$ & 47 & 108,71 & & & \\
\hline \multirow[t]{3}{*}{$\begin{array}{l}\text { Bilişsel Davranışlar } \\
\text { Alt Boyutu }\end{array}$} & $\begin{array}{l}\text { Okuma Bilmeyen- } \\
\text { İlkokul }\end{array}$ & 47 & 63,54 & 2 & 24,59 &, 000 \\
\hline & $\begin{array}{l}\text { Ortaokul- } \\
\text { Lise }\end{array}$ & 71 & 77,52 & & & \\
\hline & $\begin{array}{l}\text { Ön Lisans- } \\
\text { Lisans }\end{array}$ & 47 & 110,73 & & & \\
\hline DBÖ Toplam Puanı & $\begin{array}{c}\text { Okuma Bilmeyen- } \\
\text { İlkokul }\end{array}$ & 47 & 63,54 & 2 & 26,51 & ,000 \\
\hline
\end{tabular}




$\begin{array}{lcc}\begin{array}{l}\text { Ortaokul- } \\ \text { Lise }\end{array} & 71 & 77,13 \\ \begin{array}{c}\text { Ön Lisans- } \\ \text { Lisans }\end{array} & 47 & 111,88 \\ & & \end{array}$

Tablo 8'de yer alan analiz sonuçlarına göre; babaların öğrenim düzeyinin, DBÖ’nün toplam puanlarında ve alt boyutlarında anlamlı bir şekilde farklılaştığ görülmektedir. Bu bulgular annelerin öğrenim düzeyleri arttıkça DBÖ'nün toplam puanlarının arttı̆̆ görülmektedir $(x 2=19,68 ; \mathrm{p}<, 05)$. Ayrıca Sosyal Davranışlar $(\mathrm{x} 2=24,59 ; \mathrm{p}<, 05)$ ve Bilişsel Davranışlar alt boyutlarında $(x 2=26,51 ; \mathrm{p}<, 05)$ anlamlı bir farklılaşma olduğu görülmektedir.

Katılımcıları oluşturan okul öncesi dönem çocuklarının babalarının öğrenim düzeyi değişkenine göre OSBED Öğretmen Formunun toplam puanından ve ölçeğin alt boyutlarından elde ettikleri puanların farklılaşıp farklılaşmadığını belirlemek üzere yapılan Kruskal Wallis-H testi ile analiz edilmiştir. Bulgular Tablo 9.'da sunulmaktadır:

Tablo 9. Baba öğrenim düzeyi değişkenine göre OSBED Öğretmen Formu Toplam Puanı ve Ölçeğin Alt Boyutları için Kruskal Wallis-H testi sonuçları

\begin{tabular}{|c|c|c|c|c|c|c|}
\hline & $\begin{array}{c}\text { Baba Öğrenim } \\
\text { Düzeyi }\end{array}$ & $\mathbf{n}$ & Sira Ort. & sd & $\mathrm{x}^{2}$ & $\mathbf{p}$ \\
\hline \multirow[t]{3}{*}{$\begin{array}{l}\text { Başlangıç Becerileri } \\
\text { Alt Boyutu }\end{array}$} & $\begin{array}{l}\text { Okuma Bilmeyen- } \\
\text { İlkokul }\end{array}$ & 47 & 65,32 & 2 & 28,66 & 000 \\
\hline & $\begin{array}{l}\text { Ortaokul- } \\
\text { Lise }\end{array}$ & 71 & 74,20 & & & \\
\hline & $\begin{array}{l}\text { Ön Lisans- } \\
\text { Lisans }\end{array}$ & 47 & 113,97 & & & \\
\hline \multirow[t]{3}{*}{$\begin{array}{c}\text { Akademik Destek Becerileri } \\
\text { Alt Boyutu }\end{array}$} & $\begin{array}{l}\text { Okuma Bilmeyen- } \\
\text { İlkokul }\end{array}$ & 47 & 64,63 & 2 & 32,93 &, 000 \\
\hline & $\begin{array}{l}\text { Ortaokul- } \\
\text { Lise }\end{array}$ & 71 & 73,11 & & & \\
\hline & $\begin{array}{l}\text { Ön Lisans- } \\
\text { Lisans }\end{array}$ & 47 & 116,32 & & & \\
\hline \multirow{3}{*}{$\begin{array}{l}\text { Arkadaşlık } \\
\text { Becerileri Alt } \\
\text { Boyutu }\end{array}$} & $\begin{array}{c}\text { Okuma Bilmeyen- } \\
\text { İlkokul }\end{array}$ & 47 & 66,10 & 2 & 23,12 &, 000 \\
\hline & $\begin{array}{l}\text { Ortaokul- } \\
\text { Lise }\end{array}$ & 71 & 75,94 & & & \\
\hline & $\begin{array}{l}\text { Ön Lisans- } \\
\text { Lisans }\end{array}$ & 47 & 110,56 & & & \\
\hline \multirow{3}{*}{$\begin{array}{l}\text { Duygularını } \\
\text { Yönetme Becerileri } \\
\text { Alt Boyutu }\end{array}$} & $\begin{array}{l}\text { Okuma Bilmeyen- } \\
\text { İlkokul }\end{array}$ & 47 & 72,74 & 2 & 10,19 & ,006 \\
\hline & $\begin{array}{l}\text { Ortaokul- } \\
\text { Lise }\end{array}$ & 71 & 77,51 & & & \\
\hline & $\begin{array}{l}\text { Ön Lisans- } \\
\text { Lisans }\end{array}$ & 47 & 101,54 & & & \\
\hline \multirow{3}{*}{$\begin{array}{l}\text { OSBED Öğretmen Formu } \\
\text { Toplam } \\
\text { Puanı }\end{array}$} & $\begin{array}{c}\text { Okuma Bilmeyen- } \\
\text { İlkokul }\end{array}$ & 47 & 65,16 & 2 & 26,96 &, 000 \\
\hline & $\begin{array}{l}\text { Ortaokul- } \\
\text { Lise }\end{array}$ & 71 & 75,03 & & & \\
\hline & $\begin{array}{l}\text { Ön Lisans- } \\
\text { Lisans }\end{array}$ & 47 & 112,88 & & & \\
\hline
\end{tabular}

Tablo 9'da yer alan analiz sonuçlarına göre; babaların öğrenim düzeyinin, OSBED Öğretmen Formunun toplam puanlarında ve alt boyutlarında anlamlı bir şekilde farklılaştığı görülmektedir. Bu bulgular babaların öğrenim düzeyleri arttıkça çocukların OSBED Öğretmen Formunun toplam puanlarının, $\quad(x 2=26,96 ; p<, 05)$ arttı̆̆ 1 
görülmektedir. Ayrıca Başlangıç Becerileri (x2=28,66; $\mathrm{p}<, 05)$, Akademik Destek Becerileri $(\mathrm{x} 2=32,93$; $\mathrm{p}<, 05)$, Arkadaşlık Becerileri $(\mathrm{x} 2=23,12 ; \mathrm{p}<, 05)$ ve Duygularını Yönetme Becerileri alt boyutlarında $(\mathrm{x} 2=20,19 ; \mathrm{p}<, 05)$ anlamlı bir farklılaşma olduğu görülmektedir.

DBÖ’nün ve OSBED Öğretmen Formunun elde alt boyutlarının arasındaki ilişki Spearman's korelasyon testi ile gerçekleştirilmiştir. Bulgular Tablo 10'da sunulmaktadır:

Tablo 10. DBÖ ve OSBED Öğretmen Formundan elde alt boyutlarının arasındaki Spearman's korelasyon katsayıS1 sonuçları

\begin{tabular}{|c|c|c|c|c|}
\hline & & \multicolumn{3}{|c|}{ DBÖ } \\
\hline & & Ölçeğin Toplam Puanı & $\begin{array}{c}\text { Sosyal Davranışlar Alt } \\
\text { Boyutu }\end{array}$ & $\begin{array}{c}\text { Bilişsel Davranışlar } \\
\text { Alt Boyutu }\end{array}$ \\
\hline \multirow[t]{5}{*}{ OSBED Öğretmen Formu } & $\begin{array}{c}\text { Ölçeğin Toplam } \\
\text { Puanı }\end{array}$ & ,819 & ,718 & ,795 \\
\hline & Başlangıç Becerileri & ,746 & 650 &, 722 \\
\hline & $\begin{array}{l}\text { Akademik Destek } \\
\text { Becerileri }\end{array}$ &, 806 & ,696 & ,786 \\
\hline & Arkadaşlık Becerileri & ,749 & ,682 &, 714 \\
\hline & $\begin{array}{c}\text { Duygularını } \\
\text { Yönetme Becerileri }\end{array}$ & ,666 &, 597 & ,652 \\
\hline
\end{tabular}

Tablo 10'da yer alan analiz sonuçlarına göre; DBÖ'nün toplam puanı ve OSBED Öğretmen Formunun toplam puanları arasında yüksek düzeyde, pozitif ve anlamlı bir ilişki olduğu görülmektedir $(\mathrm{r}=, 819, \mathrm{p}<, 01)$.

OSBED Öğretmen Formunun alt boyutu olan Başlangıç Beceriler alt boyutunun Dinleme Becerileri Ölçeğinin Sosyal Davranışsal alt boyutu arasında orta düzeyde, Bilişsel Davranışlar alt boyutu arasında arasında yüksek düzeyde, pozitif ve anlamlı bir ilişki olduğu görülmektedir (Sosyal Davranışlar, $r=, 650, \mathrm{p}<, 01$; Bilişsel Davranışlar, $\mathrm{r}=, 722, \mathrm{p}<, 01)$.

OSBED Öğretmen Formunun alt boyutu olan Akademi Beceriler alt boyutunun Dinleme Becerileri Ölçeğinin Sosyal Davranışsal alt boyutu arasında orta düzeyde, Bilişsel Davranışlar alt boyutu arasında arasında yüksek düzeyde, pozitif ve anlamlı bir ilişki olduğu görülmektedir (Sosyal Davranışlar, $r=, 696, p<, 01$; Bilişsel Davranışlar, $\mathrm{r}=, 786, \mathrm{p}<, 01)$.

OSBED Öğretmen Formunun alt boyutu olan Arkadaşlık Becerileri alt boyutunun Dinleme Becerileri Ölçeğinin Sosyal Davranışsal alt boyutu arasında orta düzeyde, Bilişsel Davranışlar alt boyutu arasında arasında yüksek düzeyde, pozitif ve anlamlı bir ilişki olduğu görülmektedir (Sosyal Davranışlar, $\mathrm{r}=, 682, \mathrm{p}<, 01$; Bilişsel Davranışlar, $\mathrm{r}=, 714, \mathrm{p}<, 01)$.

OSBED Öğretmen Formunun olan Duyguları Yönetme Becerileri alt boyutunun Dinleme Becerileri Ölçeğinin Sosyal Davranışsal alt boyutu arasında orta düzeyde, Bilişsel Davranışlar alt boyutu arasında arasında yüksek düzeyde, pozitif ve anlamlı bir ilişki olduğu görülmektedir (Sosyal Davranışlar, $r=, 597, \mathrm{p}<, 01$; Bilişsel Davranışlar, $\mathrm{r}=, 652, \mathrm{p}<, 01)$.

\section{Sonuç, Tartışma ve Öneriler}

48-60 aylık çocukların dinleme becerileri ile sosyal becerileri arasındaki ilişkinin incelemesini amaçlayan bu çalışmada nicel araştırma desenlerinden ilişkisel tarama yöntemi kullanılmıştır. Araştırmanın verileri 165 çocuk için öğretmenlerinin Okul Öncesi Dönem Çocuklarına Yönelik Dinleme Becerilerini Değerlendirme Ölçeği ve Okul Öncesi Sosyal Beceri Değerlendirme Ölçeğini doldurmasıyla toplanmıştır. Bu araştırmanın sonucunda, 48-60 aylık çocukların dinleme becerileri ve sosyal becerileri arasında pozitif yönde anlamlı bir ilişki olduğu sonucuna ulaşılmıştır.

Okul öncesi dönem birçok becerinin kazanılması için kritik bir dönem olarak karşımıza çıkmaktadır. Bu dönem süresince çocuklar dinleme, konuşma ve başkalarıyla iletişim konusunda temel becerileri kazanırlar (Lapp, Flood \& Roser, 2000). Çalışmanın bulgularına bakıldığında; cinsiyet değişkenine göre kız ve erkek çocuklarının dinleme becerilerine ilişkin bulgularda, kız çocuklarının ölçekten aldığı puanların erkek çocuklara göre anlamlı şekilde farklılaştı̆̆ görülmektedir. Bu bulgu, kız çocuklarının Dinleme Becerileri Değerlendirme Ölçeğinden erkek çocuklara kıyasla daha yüksek puanlar aldığını göstermektedir. Elde edilen bulgu Bay ve Şeker'in (2020) okul öncesi dönem çocuklarının dinleme becerilerinin cinsiyetlerine göre farklılaşmadığı sonucu ve Yıldırım'ın (2007) ilkokul çocuklarının dinleme becerisi üzerine yapılan araştırmasında erkek çocukların dinleme becerilerinin daha yüksek olduğu sonucundan farklılık göstermektedir. Aynı şekilde Sosyal Becerileri Değerlendirme Ölçeğinden elde edilen bulgularda da cinsiyet değişkenine göre anlamlı farklılık olduğu ve kız çocuklarının bu ölçekten elde ettikleri puanların daha fazla olduğu görülmüştür. Bu sonuç sosyal becerilerin cinsiyete göre farklılaştığını gösteren 
araştırmalardaki sonuçları desteklemektedir (Karaca, Gündüz \& Aral, 2011). Bu doğrultuda öğretmenler çocukların sosyal becerilerine göre değerlendirme yaparken cinsiyet faktörünün farkında olmaları gerektiği görülmektedir. Bu bulgular Kapıkıran vd. (2006) okul öncesi dönem çocukların sosyal becerilerini saptamayı amaçladıkları çalışmada kız çocukların erkek çocuklara göre uyumsuz davranışlarının olması sonucundan farklılık göstermektedir. Ayrıca bu bulgu sosyal becerilerin cinsiyete göre farklılaşmadığını gösteren çalışmalardan da farklılık göstermektedir (Arı \& Yaban 2016; Aykır \& Tekinarslan, 2012; Karaoğlu \& Ünüvar, 2017). Bu farklılığın çocukların dinleme becerilerinde görülen farkl11ıklardan kaynaklanabileceği düşünülmektedir.

Çalışmanın bulgularından annenin ve babanın öğrenim düzeyine göre dinleme becerilerine ve sosyal becerilerine ilişkin bulguların anlamlı bir şekilde farklılaştığı görülmektedir. Her iki beceride de anne ve baba öğrenim düzeyi arttıkça çocukların ölçeklerden aldığı puanlar artmıştır. Bu sonuç anne ve babanın öğrenim düzeyi arttıkça çocukların sosyal becerilerinin arttığını gösteren (Karaca, Gündüz \& Aral, 2011; Elibol, 2008) çalışmaları destekleyip anne ve babanın öğrenim düzeyinin Bay ve Şeker'in (2020) çalışmasının aksine çocukların dinleme becerileri üzerinde de etkisi olduğunu göstermiştir. Yıldırım'ın (2007) ilkokul çocukları ile yapılan çalışmalarda da dinleme becerileri üzerine benzer bulguya rastlanmıştır. Bu çalışma, anne ve babaların öğrenim düzeyinin dinleme becerileri üzerinde etkileri olduğunu desteklemiş̧ir. Bu sonuç çocukların dinleme becerileri değerlendirilirken anne ve babaların öğrenim düzeyinin dikkate alınması gerektiğini göstermektedir.

Çalışmanın son bulgusu çocukların Okul Öncesi Dönem Çocuklarına Yönelik Dinleme Becerilerini Değerlendirme Ölçeği ve Okul Öncesi Sosyal Beceri Değerlendirme Ölçeğinin genel puanı ve alt boyutları arasında orta ve yüksek düzeyde pozitif yönde anlamlı ilişki olduğunu göstermiştir. Bu dinleme becerilerin çocuğun sosyal ihtiyaçları karşılayabilmek için kullandığı beceriler olduğunu (Lynch \& Simpson, 2010) desteklemekte ve çocukların sosyal becerileri ile ilişkili olduğunu göstererek alana katkı sağlayacaktır. Böylece farklı beceriler ile ilişkili olduğu incelenen dinleme becerileri (Kim \& Phillps, 2014) ile sosyal becerilerin (Bilici, 2019; Arabacıoğlu \& Bağçeli, 2020; Dinçer vd., 2019) birbiriyle olan ilişkisi de gözler önüne serilmiştir. Bu bulgu Cohen ve diğerlerinin (1993) yaptı̆̆1 çalışmayı destekler niteliktedir. Bu çalışmada öğretmen ve ebeveyn derecelendirmelerine göre davranış bozukluğu görülen çocuklarda hem alıcı ve hem de ifade edici dil gecikmeleri gözlemlenmiştir. Çocukların alıcı dilinin nasıl etkilediğini anlamak iletişim, davranışta yanlış anlaşılmalara ve çocukların davranışlarında yanlış atıfların meydana gelebilmesi açısından oldukça önemlidir (Cohen vd., 1993). Okul öncesi dönem çocukları ile yapılan bir başka çalışmada çocukların aşırı hareketli davranış gösterdiği dönemlerde dinlediğini anlama becerilerinde daha düşük sonuçlar elde edildiği görülmüştür (Cashiola, Bulotsky-Shearer \& Greenfield, 2020). Bu araştırma 48-60 aylik çocukların dinleme becerileri ve sosyal becerilerinin ilişkisini ortaya çıkartmıştır. Bu sonuç; 48-60 aylık çocukların sosyal becerilerinin desteklenmesinde dikkat edilmesi gereken bir beceri olan dinleme becerisini önemli olduğunu göstererek alana katk1 sağlayacağı düşünülmektedir.

$\mathrm{Bu}$ araştırma sonucunda 48-60 aylık çocukların dinleme becerileri ve sosyal becerileri arasında pozitif yönde anlamlı bir ilişki olduğu sonucuna ulaşılmıştır. Çocukların cinsiyetlerinin dinleme ve sosyal becerileri üzerinde $\mathrm{p} \leq, 05$ düzeyinde anlamlı fark yarattığı görülmektedir. Çocukların annelerinin ve babalarının öğrenim düzeyinin dinleme ve sosyal beceri düzeyleri üzerinde $\mathrm{p} \leq, 05$ düzeyinde anlamlı fark yarattığı görülmektedir. Annelerin ve babaların öğrenim düzeyi arttıkça çocukların dinleme ve sosyal becerilerinin arttığı sonucuna ulaşılmıştır.

$\mathrm{Bu}$ sonuçlar doğrultusunda araştırmacılara ve uygulamacılara;

- Çocukların dinleme beceriler ve sosyal becerilerini geliştirmek üzere programlar hazırlanırken bu iki becerinin birbiriyle olan ilişkisinin dikkate alınması,

- Öğretmenler bu becerilerin kazanılmasında anne-babaların öğrenim düzeyi, çocuğun cinsiyeti değişkenlerin etkili olabileceğini göz önünde bulundurmaları,

- Çocukların dinleme becerileri üzerinde farklı değişkenler üzerine çalışmalar yapılması,

- Çocukların dinleme ve sosyal becerilerini geliştirmek amacıyla ortak programlar hazırlanması ve uygulanması önerilmektedir.

Yazarlar çalışmaya eşit oranda katkı sunmuşlardır.

\section{Araştırmacıların Katkı Oranı}

\section{Destek ve Teşekkür}

Yazarlar çalışma için herhangi bir finansal destek almamışlardır.

Çıkar Çatışması

Yazarlar çalışmada herhangi bir çıkar çatışmasının bulunmadığını beyan etmişlerdir. 


\section{Kaynakça / References}

Abalı, B. Y., \& Yazıc1, H. (2020). An evaluation on determining the relation between listening skill and social emotional learning skill. Eurasian Journal of Educational Research, 89. 71-92

Arabacıoğlu, B., \& Bağçeli Kahraman, P. (2020). Sosyal beceri eğitiminin 60-69 aylık Suriyeli çocukların sosyal becerileri, problem çözme ve uyum sağlamalarına etkisi. Çukurova Üniversitesi Eğitim Fakültesi Dergisi, 49(2), 734-768.

Arı, M., \& Yaban, E. H. (2016). Okul öncesi dönemdeki çocukların sosyal davranışları: Mizaç ve duygu düzenlemenin rolü. Hacettepe Üniversitesi Ĕ̈itim Fakültesi Dergisi, 31(1), 125-141.

Aviles, A. M., Anderson, T. R., \& Davila, E. R. (2006). Child and adolescent social-emotional development within the context of school. Child and Adolescent Mental Health, 11(1), 32-39.

Aykır, T., \& Tekinarslan, İ. (2012). Okul öncesi dönemdeki zihinsel yetersizliği olan ve olmayan çocukların sosyal becerileri ve problem davranışlarının karşılaştırılması. Kastamonu Eğitim Dergisi, 20(2), 627-648.

Bay, D. N., \& Seker, P. T. (2020). Analysis of preschool period children's listening skill according to some variables. World Journal of Education, 10(3), 79-87.

Benner, G. J., Rogers-Adkinson, D., Mooney, P., \& Abbott, D. A. (2007). An investigation of the relationship between receptive language and social adjustment in a general sample of elementary school children. Journal of At-Risk, 13(1), 13-21.

Bilici, H. S. (2019). Okul öncesi eğitim kurumlarına devam eden 60-72 devam eden sosyal duygusal uyumları, problem çözme becerileri ve rekabet ile ilişkinin ilişki ilişkileri (Yayınlanmamış yüksek lisans tezi). Marmara Üniversitesi, İstanbul.

Cashiola, E. B., Bulotsky-Shearer, R. J., \& Greenfield, D. B. (2020). Bidirectional associations between preschool classroom behavior and language and literacy skills. Topics in Early Childhood Special Education, 40(3), 143-158.

Cihangir-Çankaya, Z. (2015). Kişiler arası ilişkiler ve iletişimde dinleme. A. Kaya (Ed.), Kişiler arası ilişkiler ve etkili iletişim içinde (ss. 93-108). Ankara: Pegem Yayınları.

Cillessen, A. H. N., \& Bellmore, A. D. (2010). Social skills and social competence in interactions with peers. In P. K. Smith \& C. H. Hart (Eds.), The Wiley-Blackwell Handbook of Childhood Social Development (pp. 393-412). Hoboken, NJ: WileyBlackwell.

Cohen, N. J., Davine, M., Horodezky, N., Lipsett, L., \& Isaacson, L. (1993). Unsuspected language 1mpairment in psychiatrically disturbed children: prevalence and language and behavioral characteristics. Journal of the American Academy of Child \& Adolescent Psychiatry, 32(3), 595-603.

Creswell, J. W. (2017). Ĕgitim araştırmaları: Nicel ve nitel araştırmanın planlanması, yürütülmesi ve değerlendirilmesi (Çev. Ed. H. Ekşi). İstanbul: Edam.

Çinar, F. (1990). The effects of early childhood education on children's social development (Unpublished master thesis), Bogazici University, Istanbul, Turkey.

Dinçer, Ç., Baş, T., Teke, N., Aydın, E., İpek, S., \& Göktaş, Ş. (2019). Okul öncesi dönem çocuklarının kişilerarası problem çözme ve sosyal becerileri ile akran ilişkilerinin değerlendirilmesi. Bolu Abant İzet Baysal Üniversitesi Eğitim Fakültesi Dergisi, 19(3), 882-900.

Ekici, F. Y. (2017). Okul öncesi eğitim kurumlarındaki aile katılım çalışmalarına katılan ve katılmayan ailelerin çocuklarının sosyal beceri ve problem davranışları arasındaki ilişki. Hitit Üniversitesi Sosyal Bilimler Enstitüsü Dergisi, $10(1)$, $543-562$.

Elibol, G. S. (2008). Beş yaş çocuklarının sosyal becerilerinin bazı değişkenler açısından değerlendirilmesi (Yayınlanmamış yüksek lisans tezi). Ankara Üniversitesi, Ankara.

Ergin, D. Y., \& Ermeğan, B. (2011). Çok kültürlülük ve sosyal uyum. 2nd International Conference on New Trends in Education and Their Implications, 27-29 April, Antalya, Turkey.

Estrem, T. L. (2005). Relational and physical aggression among preschoolers: The effect of language skills and gender. Early Education and Development, 16(2), 207-231. 
Florit, E., Roch, M., Altoè, G., \& Levorato, M. C. (2009). Listening comprehension in preschoolers: the role of memory. The British Journal of Developmental Psychology, 27(Pt 4), 935-951.

Gresham, F. M. \& Elliott, S. N. (1990). Social skills rating system. Circle Pines, MN: American Guidance Service.

Gülay, H., \& Yenibayrak, F. (2010). 5-6 yaş çocukları için sosyal beceri etkinlikleri. Ankara: Pegem A.

Kapıkıran, N. A., İvrendi, A., \& Adak, A. (2006). Okul öncesi çocuklarında sosyal beceri: durum saptaması. Pamukkale Üniversitesi Eğitim Fakültesi Dergisi, 19(19), 19-27.

Karaca, N. H, Gündüz, A., \& Aral, N. (2011). Okul öncesi dönem çocuklarının sosyal davranışının incelenmesi, Kuramsal Ĕ̈itimbilim, 4(2), 65-76.

Karadüz, A. (2010). Türkçe ve sınıf öğretmeni adaylarının dinleme stratejilerinin değerlendirilmesi. Erciyes Üniversitesi Sosyal Bilimler Enstitüsü Dergisi, 29, 39-55.

Karoğlu, H., \& Ünüvar, P. (2017). Okul öncesi dönem çocuklarının gelişim özellikleri ve sosyal beceri düzeyleri. Mehmet Akif Ersoy Üniversitesi Eğitim Fakültesi Dergisi, (43), 231-254.

Kemiksiz, Ö. (2017). Dinleme becerisi üzerine yazılan makalelerin değerlendirilmesi. International Journal of Languages Education, 5(1), 511-531.

Kim, M. J., Doh, H. S., Hong, J. S., \& Choi, J. S. (2011). Social skills training and parent education programs for aggressive preschoolers and their parents in South Korea. Children and Youth Services Review, 33(6), 838-845.

Kim, Y.-S. \& Phillps, B. (2014). Cognitive correlates of listening comprehension. Reading Research Quarterly, 49(3), $269-281$.

Lapp, D., Flood, J., \& Roser, N. (2000) Still standing: timeless strategies for teaching the language arts. In D. S. Strickland \& L. M. Morrow (Eds.), Beginning reading and writing (pp. 183-193). New York, NY: Teachers College Press.

Lynch, S. A., \& Simpson, C. G. (2010). Social skills: Laying the foundation for success. Dimensions of Early Childhood, 38(2), 311.

Morgeson F. P., Reider, M. H., \& Campion, M. A. (2005). Selecting individuals in team setting: The importance of social skills, personality characteristics and teamwork knowledge. Personnel Psychology, 58(3), 583-611.

Ömeroğlu, E., Büyüköztürk, Ş., Aydoğan, Y., Çakan, M., Kılıç Çakmak, E., Özyürek, A., ... Karayol, S. (2014). Okul öncesi sosyal beceri değerlendirme ölçeği öğretmen formunun geliştirilmesi: Geçerlik ve güvenirlik analizleri. Eğitim Bilimleri ve Sosyal Araştırmalar Dergisi, 3(8), 37-46.

Özbay, M. (2001). Türkçe öğretiminde dinleme becerisini geliştirme yolları. Türk Dili Dergisi, (589), 9-15.

Özbek, A. (2003). Okul öncesi ĕgitim kurumlarına devam eden etmeyen çocukların ilköğretim birinci sınıfta sosyal gelişim açısından öğretmen görüşüne dayalı olarak karşılaştırılması (Yayınlanmamış yüksek lisans tezi). Anadolu Üniversitesi, Eskişehir.

Özer-Özkan, Y., \& Coşkun, L. (2015). Okul öncesi dönem çocuklarına yönelik dinleme becerilerini değerlendirme ölçeğinin geliştirilmesi. Kalem Uluslararası Eğitim ve İnsan Bilimleri Dergisi, 5(9), 67-98.

Porath, M. (2003). Social understanding in the first year of school. Early Childhood Research Quarterly, 18(4), $468-484$.

Saitoğlu, R. (2020). Okul öncesi çocukların sosyal becerileri ile problem davranışlar ve akran ilişkilerinin sosyo-demografik değişkenlere göre incelenmesi (Yayınlanmamış yüksek lisans tezi). Çağ Üniversitesi, Mersin.

Türnüklü, A. (2004). Okullarda sosyal ve duygusal ögrenme. Kuram ve Uygulamada Ĕ̆itim Yönetimi, (37), $136-152$.

Uğur, H. (1998). Anasınıfi eğitiminin sosyalleşmedeki rolü ve öğrencileri sosyalleştirme açısından özel ve devlet anasınıflarının karşılaştırması (Yayınlanmamış yüksek lisans tezi). Sakarya Üniversitesi, Sakarya.

Verduyn, C. M., Lord, W., \& Forrest, G. C. (1990). Social skills training in schools. Journal of Adolescence, 13(3), 4-16.

Yıldırım, H., (2007). Illköğretim üçüncü sınıf öğrencilerinin dinleme becerileri üzerine bir araştırma (Yayımlanmamış yüksek lisans tezi). Abant İzzet Baysal Üniversitesi, Bolu. 